\section{Characterization and Evaluation of Antimicrobial Activity of Bacteriocins from Lactobacillus Curvatus and Pediococcus Pentosaceus}

\author{
Mona E Elyass ${ }^{1 *}$, Marei Ahmed Altayar ${ }^{2}$, Ahmed A Mahdi,3*, \\ Suliman S Abdelrawaf ${ }^{4}$, MT Shigidi ${ }^{3}$ and Idress H Attitalla ${ }^{4 *}$ \\ ${ }^{1}$ National Council for Research, Khartoum, Sudan \\ ${ }^{2}$ Department of Microbiology, University of Benghazi, Benghazi, Libya \\ ${ }^{3}$ Department of Agriculture, University of Khartoum, Sudan \\ ${ }^{4}$ Department of Microbiology, Omar Al-Mukhtar University, Al-Bayda, Libya
}

\begin{abstract}
Lactobacillus curvatus $\mathrm{M} 3$ and Pediococcus pentosaceus $\mathrm{N} 2$, isolated from fermented beef and infant faeces, respectively, exhibited antibacterial activity against Staphylococcus aureus, Bacillus subtilis, Enterococcus faecalis, Escherichia coliATCC25922, Klebsiella pneumonia, Proteus vulgaris, Pseudomonas aeruginosa and Salmonella typhi. The activity was not due to $\mathrm{H}_{2} \mathrm{O}_{2}$ as similar inhibition was obtained by supernatants produced under aerobic or anaerobic growth conditions. The active ingredients were identified as bacteriocins of molecular mass of 3-4 $\mathrm{kDa}$. The two bacteriocins were sensitive to proteinase-k and pepsin but were not affected by a-amylase, and experienced little reduction in activity on heating to $100^{\circ} \mathrm{C}$ for $30 \mathrm{~min}$ but were destroyed by autoclaving. Both bacteriocins exhibited highest inhibitory activity at $\mathrm{pH}$ 5.0. The bacteriocin from $L b$. curvatus $\mathrm{M} 3$ was bactericidal while that from N2 was bacteriostatic to Staph. aureus. Kinetics of growth and bacteriocin production showed that maximal inhibitory activity coincided with the phase of optimal growth and with a drop in the $\mathrm{pH}$ of the growth medium to 4.2-4.5.
\end{abstract}

Keywords: Lactobacillus curvatus, Pediococcus pentosaceus, Bacteriocins

*Corresponding author: Mona E Elyass, National Centre for Research 2404, Khartoum, Sudan, Tel: +2499614415365; E-mail: monadaliaya@gmail.com

Ahmed A Mahdi, Department of Microbiology, Omar Al-Mukhtar University, Al-Bayda, Libya, Tel: +218 911453987; E-mail: mahdi.ahmed34@gmail.com

Idress Hamad Attitalla, Department of Microbiology, Omar El-Mukhtar University, Al-Bayda, Libya, Tel: +218 913998351; E-mail: idressattitalla2004@yahoo.com

Citation: Elyass ME, Altayar MA, Mahdi AA, Abdelrawaf SS, Shigidi MT, et al. (2015) Characterization and Evaluation of Antimicrobial Activity of Bacteriocins from Lactobacillus Curvatus and Pediococcus Pentosaceus. J Infect Non Infect Dis 1: 001.

Received: February 27, 2015; Accepted: May 14, 2015; Published: May 28 2015

\section{Introduction}

Food consumers are nowadays concerned about the synthetic chemicals used as preservatives in food, with a noticeable inclination toward less processed foods, but it has to be remembered that untreated foods can harbor dangerous pathogens [1].

One of the oldest food processing techniques known to man is food fermentation. Since the dawn of civilization, methods for the fermentation of milk, meat and vegetables have been known [2]. Fermentations resulted in the development of foods with good keeping qualities and organoleptically desirable characteristics. The fermentation processes were generally artisan in nature, unaware of the role of microorganisms [3].

By the middle of the $19^{\text {th }}$ century, the roles of the main microbial groups responsible for these fermentations, such as the Lactic Acid Bacteria (LAB), were being understood, and their activities started to be controlled and manipulated. Although fermentations originally aimed at preserving the fermented food items, other attributes of the process, such as imparting of unique flavors, textures and aromas, and enhancement of the keeping quality and microbiological safety, have gained prominence [3].

$\mathrm{LAB}$ have an important role in the inhibition of food-borne pathogenic and spoilage microorganisms such as Listeria monocytogenes, Clostridium sp and Staphylococcus sp [4]. LAB display a wide range of antimicrobial activities, important among which is the production of lactic and acetic acids. Moreover, certain strains of LAB are further known to produce bioactive molecules such as ethanol, formic acid, fatty acids, hydrogen peroxide, diacetyl, reuterin and reutericyclin [5]. In addition, many strains also produce bacteriocins and bacteriocin-like molecules that display antibacterial activity [6].

Screening for bacteriocins during the last few decades has yielded a myriad of bacteriocins with different properties, indicator species and producer organisms [7]. This has prompted researchers worldwide to pursue exploration in this area of natural and safe antimicrobial compounds. The aim of this study was to: (i) screen for the presence of bacteriocion-producing LAB in fermented beef and newborn infant faeces, (ii) characterize the bacteriocins for their heat and $\mathrm{pH}$ stability, enzyme action and their inhibitory spectrum against a wide range of bacteria.

\section{Materials and Methods}

\section{Isolation and characterization of the bacteriocinogenic bacteria}

Two bacterial isolates, coded M3 and N2, were isolated from traditional fermented Sudanese beef (sharmoot) and newborn infant's faeces, respectively. They were subsequently purified by streaking on de Man, Rogosa, Sharpe (MRS) agar [8], and the streaked plates were incubated anaerobically at $30^{\circ} \mathrm{C}$ for $2-3$ days using an anaerobic jar system (GasPak; BBL Microbiology Systems, Cockeysville, Maryland, USA) with a gas-generating kit (BR0038B, Oxoid, Hampshire, UK ). The two isolates were first identified to the generic level based on their physiological and biochemical characteristics making use of accepted schemes of classification [9-12]. They were initially 
examined for Gram reaction, catalase production, cell morphology using phase contrast microscopy, gas production from glucose, hydrolysis of arginine, growth at $\mathrm{pH} 4.4$ and 9.6, salt tolerance and growth at $10^{\circ} \mathrm{C}$ and $45^{\circ} \mathrm{C}$.

Gas production from glucose was determined in modified MRS broth containing inverted Durham tubes with diammonium citrate replaced by ammonium sulphate [13]. Glucose was sterilized separately $\left(115^{\circ} \mathrm{C}\right.$ for $\left.10 \mathrm{~min}\right)$ and was aseptically added to the medium. Hydrolysis of arginine was tested in MRS broth without glucose or meat extract but containing $0.3 \%$ arginine and $0.2 \%$ sodium citrate instead of ammonium citrate. Ammonia was detected using Nessler's reagent [14]. Growth at $\mathrm{pH} 4.4$ and 9.6 was tested in MRS broth adjusted to these $\mathrm{pH}$ values using $1 \mathrm{~N} \mathrm{HCl}$. Salt tolerance was tested in MRS broth supplemented with $6.5 \% \mathrm{NaCl}$. Growth at different temperatures was observed in MRS broth after incubation for 3 days at $15^{\circ} \mathrm{C}$ and $45^{\circ} \mathrm{C}$.

Ultimately, the two isolates were identified to specific level through biochemical profiling using the KB009 HiCarbohydrate identification kit (HiMedia Laboratories, Mumbai, India), which makes use of the patterns of utilization of 35 sugars.

\section{Screening for antagonistic activity}

The antagonistic activities of the two isolates against four indicator bacteria (Staphylococcus aureus ATCC43306, Bacillus subtilis NCTC8236, Enterococcus faecalis ATCC10541 and Escherichia coli ATCC25922) were initially screened by the direct spot-on-lawn method [15] which was afterwards confirmed by the agar-well diffusion method [16].

In the spot-on-lawn method, aliquots of about $20 \mu \mathrm{L}$ of 48 -h old MRS broth cultures of each isolate were spotted on the surface of MRS agar plates $(1.5 \%$ agar $)$ and were aerobically incubated at $35^{\circ} \mathrm{C}$ for $24 \mathrm{~h}$. Twenty-four-h old physiological saline-washed cells of indicator bacteria [17] to be tested for sensitivity were inoculated $(0.2 \mathrm{~mL}$ of a $10^{5} \mathrm{CFU} / \mathrm{mL}$ bacterial suspension) into $7.0 \mathrm{~mL}$ of soft Nutrient Agar medium $(0.8 \%$ agar $)$. The seeded soft agar was poured as an overlay onto the MRS plates on which the test bacteria had grown for $24 \mathrm{~h}$ (deferred antagonism). The antagonism was detected by the formation of a growth inhibition halo of the indicator microorganism around bacteriocinogenic test isolates.

In the agar-well diffusion method, cell-free supernatants of M3 and N2 were used to inhibit growth of the indicator bacteria. The cell-free supernatants were prepared following the method of Çadirci and Çitak (2005) [17] in which 24-h old cultures were used to inoculate MRS broth (2\%) in test tubes. The inoculated tubes were incubated at $30^{\circ} \mathrm{C}$ for 24,48 and $72 \mathrm{~h}$ without shaking. At the end of the incubation period the broth cultures were centrifuged at $6000 \mathrm{~g}$ for $15 \mathrm{~min}$ in a centrifuge (EBA20, Zentrifugen, Tuttlingen, Germany). The cell-free supernatants were carefully decanted, filter-sterilized (pore size $0.22 \mu \mathrm{m}$, Millipore, Bedford, Mass., USA) and were kept at $4^{\circ} \mathrm{C}$ for use in the determination of their antagonistic activities against the four indicator bacteria, and for their characterization.

The test for spectrum of inhibition was later extended to cover another six bacteria, namely, Staph. aureus ATCC25923, E. coli (local isolate), Pseudomonas aeruginosa ATCC27853, Klebsiella pneumoniae ATCC10031, Proteus vulgaris ATCC6380 and Salmonella typhi ATCC1319106. To test for antagonism, molten Nutrient Agar $\left(45-48^{\circ} \mathrm{C}\right)$ (Oxoid,) medium was first seeded with washed cells of the indicator bacteria, and the inoculated medium was immediately poured into sterile Petri dishes. After solidification, the medium was allowed to dry for at least 30 minutes at room temperature. Four wells of uniform diameter (about $5 \mathrm{~mm}$ ) were aseptically bored in the agar using a sterile Pasteur pipette. Fifty $\mu \mathrm{L}$ of the cell-free supernatants of each test isolate were dispensed into each of three wells (replicates), while sterile MRS broth was poured into the fourth well to serve as a control treatment. Plates were left to stand for at least five $\mathrm{h}$ at room temperature to allow diffusion of the cell-free extracts. The plates were then incubated at $30^{\circ} \mathrm{C}$ for $24 \mathrm{~h}$. At the end of the incubation period, diameters of the resulting inhibition zones, if any, were measured and the results recorded in $\mathrm{mm}$.

\section{Characterization of the cell-free supernatants}

Partial purification of the supernatants: For partial purification of the cell-free supernatants, a modification of the method of Brink et al., [18] was adopted, in which $50 \mathrm{~mL}$ of $n$-butanol and $5 \mathrm{~g} \mathrm{NaCl}$ were added to $50 \mathrm{~mL}$ of cell-free supernatant, mixed well and the mixture was centrifuged $(6000 \mathrm{~g})$ for 10 minutes. The $n$-butanol was then evaporated at $45^{\circ} \mathrm{C}$ and the residue was resuspended in $50 \mathrm{~mL}$ saline $(9 \mathrm{~g} \mathrm{NaCl} / \mathrm{L})$. The partially purified supernatants were used for determination of their characteristics and their antagonistic activities against Staphylococcus aureus ATCC43306.

\section{Sensitivity of the partially purified supernatants to enzymes}

Sensitivity of the partially purified supernatants to the effects of various enzymes, including proteolytic ones, was conducted as suggested by Barefoot and Klaenhammer (1983) [16]. The partially purified supernatants were adjusted to $\mathrm{pH} 6.0$ with $1 \mathrm{~N} \mathrm{NaOH}$. One $\mathrm{mL}$ of each supernatant was incubated at $37^{\circ} \mathrm{C}$ for $1 \mathrm{~h}$ in the presence of the proteolytic enzymes proteinase-K (Vivantis Technologies Sdn Bhd, Revongen Corporation Center, Subang Taya, Selangor DE, Malaysia), pepsin (Sigma Chemical Co., St. Louis, Mo.), and a-amylase (Mühlenchemie GmbH, Ahrensburg, Germany). Enzymes were added to a final concentration of $2.0 \mathrm{mg} / \mathrm{mL}$. Enzyme-free supernatants, as well as medium with no supernatant or enzyme were used as controls. Residual antimicrobial activity was assayed by the agar well-diffusion method using Staphylococcus aureus ATCC 43306 as the indicator organism.

\section{Heat and pH stability}

The effect of heat on the partially purified supernatants was tested, as described by Ivanova et al., [19], by heating the supernatants to 40 , 60 and $100^{\circ} \mathrm{C}$ for 10,30 and $60 \mathrm{~min}$ at each temperature in a water bath (No. Y22, Grant Instruments, Cambridge, UK). Moreover, an additional treatment of autoclaving the supernatants at $121^{\circ} \mathrm{C}$ for 15 minutes was included. The residual antagonistic activity was assayed as above. The $\mathrm{pH}$ stability was also tested by the method of Ivanova et al., [19]. Supernatants were adjusted to $\mathrm{pH}$ 3.0, 5.0, 7.0 and 9.0 with $1 \mathrm{M} \mathrm{HCl}$ or $1 \mathrm{M} \mathrm{NaOH}$. The supernatants were then incubated at $37^{\circ} \mathrm{C}$ for $4 \mathrm{~h}$ after which the $\mathrm{pH}$ values were re-adjusted to 6.0 for all treatments. Inclusion of the $\mathrm{pH}$ values of 7.0 and 9.0 also served for exclusion of the effect of any acids that might be produced by the test isolates. Residual antimicrobial activity was also determined as above.

\section{Production of the inhibitory factor during anaerobic growth}

To exclude any possible inhibition due to production of hydrogen peroxide $\left(\mathrm{H}_{2} \mathrm{O}_{2}\right)$ by the test isolates, the technique of Lewus et al., [20] was followed. Each isolate was grown under anaerobic conditions for $24 \mathrm{~h}$ at $35^{\circ} \mathrm{C}$ in an anaerobic jar system (GasPak; BBL). At the end 
of the incubation period, cell-free supernatants were prepared as described above. Antagonistic activities of these supernatants against the indicator bacterium were assayed by the agar well-diffusion method.

\section{Molecular mass determination}

The active peptides in the cell-free filter-sterilized supernatants of the two bacterial isolates were first precipitated by addition of $40 \%(\mathrm{w} / \mathrm{v})$ ammonium sulfate, centrifuged (6000rpm, 15min), and their pellets and pellicles were concentrated and used for protein separation by Tricine- sodium dodecyl sulfate polyacrylamide gel electrophoresis (Tricine-SDS-PAGE) using 15\% acrylamide. The gel electrode assembly was placed in a Mini PROTEAN II electrophoresis chamber (Biorad Laboraties, Hercules, CA), and the proteins were electrophoresed at 100 volts for about $2 \mathrm{~h}$. A protein molecular mass marker (MoBiTec GmbH, Rastatt Germany) with a molecular weight range of 14.0 to $116.0 \mathrm{kDa}$ was included. Staining of the gels was done by covering with Coomassie blue stain overnight. The Coomassie blue stain was composed of $5.75 \mathrm{~mL}$ glacial acetic acid, $0.157 \mathrm{~g}$ Coomassie blue dye, $28.5 \mathrm{~mL}$ methanol and $62.5 \mathrm{~mL}$ deionized water. The preparations were destained with a buffer composed of $10.0 \mathrm{~mL}$ glacial acetic acid, $50.0 \mathrm{~mL}$ methanol and $100 \mathrm{~mL}$ deionized water.

\section{Mode of action of the partially-purified supernatants}

To find out whether the antagonistic effects of the supernatants were bactericidal or bacteriostatic in nature, we followed a procedure similar to that described by Faye et al., [21] and Nilsen et al., [22] in which $4-\mathrm{mL}$ aliquots of the supernatant were added to $20 \mathrm{~mL}$ of a suspension of physiological-saline-washed 24-h old Staphylococcus aureus ATCC43306 cells (ca. $10^{6} \mathrm{CFU} / \mathrm{mL}$ ) in Nutrient Broth in a McCartney bottle. S. aureus cells were first allowed to grow for four $\mathrm{h}$ before addition of the supernatant and their optical densities $\left(\mathrm{OD}_{540}\right)$ were recorded at hourly intervals. Thenceforth, optical densities were measured at hourly intervals for five more hours. The investigation was terminated by plating aliquots on Nutrient Agar plates and incubating at $35^{\circ} \mathrm{C}$ for $24 \mathrm{~h}$ to detect growth.

\section{Kinetics of growth and bacteriocin production}

The procedure followed to determine the kinetics of growth and production of the antagonistic activity was similar to that described by Ghrairi et al., [23]. MRS broth $(250 \mathrm{~mL})$ was inoculated with $1 \%$ of an overnight culture of each strain and incubated at $30^{\circ} \mathrm{C}$ without agitation under uncontrolled $\mathrm{pH}$ conditions. Samples were removed at hourly intervals up to $13 \mathrm{~h}$, and then at 24,25 and $26 \mathrm{~h}$ from start of the investigation. Measurement of biomass by absorbance at $600 \mathrm{~nm}$, $\mathrm{pH}$ measurement and determination of the antibacterial activity were carried out by assaying the effect of serial two-fold dilutions of partially purified bacteiocins on Staphylococcus aureus ATCC 43306 by the well-diffusion method. The antimicrobial titer was expressed in arbitrary units $(\mathrm{AU} / \mathrm{mL})$. One arbitrary unit was defined as the reciprocal of the highest dilution showing a clear inhibition zone around the well [24].

\section{Results and Discussion}

\section{Spectrum of antibacterial activity}

The two bacterial isolates were characterized as follows: Isolate M3 was a Gram-positive, facultatively anaerobic none-spore-forming catalase-negative rod which was identified as Lactobacillus curvatus, while isolate N2 was a Gram-positive facultatively anaerobic catalase-negative coccus identified as Pediococcus pentosaceus. On initial screening, both L. curvatus M3 and P. pentosaceus N2 could produce wide inhibition zones against all four indicator bacteria (Staph. aureus, Bacillus subtilis, Enterococcus faecalis and E. coli) by the spot-on-lawn method as well as the agar well-diffusion test. Table 1 shows results of inhibition of the four indicator bacteria by cell-free extracts obtained from the two isolates after incubation for 24,48 and $72 \mathrm{~h}$. Plate 1 depicts zones formed by extracts from P. pentosaceus N2 against three of the indicator bacteria.

Screening for the spectrum of inhibitory activity showed that seven of the 10 test bacteria were inhibited by both bacteriocins, but they could not inhibit Pseudomonas aeruginosa, Salmonella typhi or the local E. coli isolate (Table 2). Production by Lb. curvatus of different bacteriocins has been reported by many authors. For instance, Lb. curvatus LTH1174 produced curvaticin A $[25,26]$, Lb. curvatus ACU-1 produced sakacin Q [27], Lb. curvatus FS47 produced curvaticin FS47 [28], Lb. curvatus L442 produced curvaticin L442 [29], and Lb. curvatus CRL705 produced lactocin 705 [30,31]. It has been shown that curvaticin LB65 produced by Lb. curvatus was inhibitory to Listeria monocytogenes, Staph. aureus, Enterococcus faecalis, Micrococcus leuteus, Klebsiella pnumoniae, E. coli and many $\mathrm{LAB}[32]$.

Bacteriocins produced by pediococci are known to have a relatively broad spectrum of activity, and are produced by P. pentosaceus and P. acidilactici [22]. P. pentosaceus has been reported to produce a variety of bacteriocins such as pediocin N5p [33], pediocin ST18 [34] and pediocin PA-1 which is produced by P. pentosaceus TISTR536 [35]. Bacteriocins from P. pentosaceus have been shown to inhibit many bacterial genera. Pediocin A, produced by Pediococcus pentosaceus FBB61, exhibited inhibition against species of Lactobacillus, Lactococcus, Leuconostoc, Pediococcus, Staphylococcus, Enterococcus, Listeria and Clostridium [36]. It has also been reported that a bacteriocin from Pediococcus pentosaceus ST44AM was active against lactic acid bacteria, Escherichia coli, Pseudomonas aeruginosa, Klebsiella pneumoniae, Listeria innocua, Listeria ivanovii subsp. ivanovii and Listeria monocytogenes [37].

\section{Sensitivity to enzymes}

No inhibition of the indicator bacterium (Staphylococcus aureus) was produced by the partially-purified supernatants in presence of the protein-digesting enzymes (proteinase-k and pepsin) indicating complete digestion of the inhibitory substance in the supernatants, and asserting its proteinaceous nature; while no reduction in the inhibitory activity was observed in the presence of the carbohydrate-degrading $a$-amylase. No inhibitory activity was shown in the uninoculated medium containing no enzyme (negative control) (Table 3). The inhibition by supernatants from both isolates was not due to production of $\mathrm{H}_{2} \mathrm{O}_{2}$ as the diameters of inhibition zones due to supernatants produced during aerobic or anaerobic growth conditions were similar (data not shown). These results are enough evidence of the bacteriocin nature of the active ingredient in these supernatants since bacteriocins are usually defined as ribosomally synthesized proteinaceous compounds released extracellularly by bacteria that can be shown to interfere with the growth of other bacteria, typically including some that are closely related to the producing bacterium and to which the producer cell expresses a degree of specific immunity [38]. 
Citation: Elyass ME, Altayar MA, Mahdi AA, Abdelrawaf SS, Shigidi MT, et al. (2015) Characterization and Evaluation of Antimicrobial Activity of Bacteriocins from Lactobacillus Curvatus and Pediococcus Pentosaceus. J Infect Non Infect Dis 1: 001.

- Page 4 of $7 \bullet$

\begin{tabular}{|c|c|c|c|c|c|c|c|c|c|c|c|c|}
\hline \multirow{2}{*}{ Test strain } & \multicolumn{3}{|c|}{ Staph. aureus } & \multicolumn{3}{|c|}{ B. subtilis } & \multicolumn{3}{|c|}{ Ent. faecalis } & \multicolumn{3}{|c|}{ E. coli } \\
\hline & $24 \mathrm{~h}$ & $48 h$ & $72 \mathrm{~h}$ & $24 \mathrm{~h}$ & $48 \mathrm{~h}$ & $72 \mathrm{~h}$ & $24 h$ & $48 h$ & $72 \mathrm{~h}$ & $24 \mathrm{~h}$ & $48 h$ & $72 \mathrm{~h}$ \\
\hline L.curvatus M3 & ++ & ++ & ++ & ++ & ++ & ++ & + & ++ & + & ++ & ++ & ++ \\
\hline
\end{tabular}

Table 1: Inhibition zones produced against four indicator bacteria by cell-free extracts obtained after 24,48 and $72 \mathrm{~h}$ of growth.

$+=6-12 \mathrm{~mm}$ zone diameter; ++ = 13-19 $\mathrm{mm} ;+++=>20 \mathrm{~mm}$

\begin{tabular}{|c|c|c|c|c|c|c|c|c|c|}
\hline Test strain & Ent.faecalis & B. subtilis & $\begin{array}{c}\text { Staph. } \\
\text { aureus }\end{array}$ & $\begin{array}{c}\text { Staph. } \\
\text { aureus }\end{array}$ & P. aeruginosa & K. pneumoniae & $\begin{array}{c}\text { Proteus } \\
\text { vulgaris }\end{array}$ & $\begin{array}{c}\text { S. typhi } \\
\text { ATCC 25922 }\end{array}$ & $\begin{array}{c}\text { E. coli } \\
\text { (local) }\end{array}$ \\
\hline L.curvatus M3 & 13 & 16 & 10 & 15 & 0.0 & 9 & 10 & 0.0 & 6 \\
\hline P. pentosaceus N2 & 12 & 14 & 15 & 18 & 0.0 & 6 & 11 & 0.0 & 10 \\
\hline
\end{tabular}

Table 2: Spectrum of inhibitory activity against ten indicator tbacteria (zone diameters, $\mathrm{mm}$ ).

\begin{tabular}{|c|c|c|c|c|c|}
\hline Test strain & Proteinase-K & Pepsin & $\boldsymbol{\alpha}$-amylase & Enzyme-free supernatants & Medium with no enzyme or supernatant \\
\hline L.curvatus M3 & 0.0 & 0.0 & 13 & 13 & 0.0 \\
\hline P. pentosaceus N2 & 0.0 & 0.0 & 13 & 14 & 0.0 \\
\hline
\end{tabular}

Table 3: Effect of enzymes on activity of cell-free supernatants obtained from two LAB isolates against Staph. aureus ATCC 43306 (Inhibition zone diameters in mm).

\section{Heat and pH stability}

No reduction was observed in the activity of the bacteriocin from of $L$. curvatus $\mathrm{M} 3$ on heating to $40^{\circ} \mathrm{C}$ for 10 minutes (Figure 1a), but a reduction of $17.6 \%$ was observed on heating for 30 or 60 minutes. When the supernatant was heated at $60^{\circ} \mathrm{C}$, a reduction of $35.3 \%$ was observed whether heated for 10,30 or 60 minutes. On heating to $100^{\circ} \mathrm{C}$, a reduction of $17.6 \%$ was observed after 10 minutes, with further reduction on extending the heating period to 30 or 60 minutes. On the other hand, no reduction in activity was observed on heating the bacteriocin from P. pentosaceus N2 to 40,60 or $100^{\circ} \mathrm{C}$ for 10 or 30 minutes, but on heating at these temperatures to 60 minutes, a reduction of $54 \%$ was recorded, and no activity was detected in autoclaved supernatant even after just 10 minutes (Figure 1b). It was found that the bacteriocin produced by Pediococus pentosaceus (VTCC-B-601) was stable as even heating at $100^{\circ} \mathrm{C}$, for 30 minutes or autoclaving at $121^{\circ} \mathrm{C}$ for 15 minutes [39].

As for the effect of $\mathrm{pH}$ on stability, L. curvatus bacteriocin showed highest activity at $\mathrm{pH} 5.0$ and a decline at $\mathrm{pH} 3.0,7.0$ and 9.0. However, the reduction in inhibitory activity was not great, amounting only to $16.7 \%$ at $\mathrm{pH} 9.0$ (Figure 2). The highest inhibitory activity by the $P$. pentosaceus bacteriocin was recorded at $\mathrm{pH} 5.0$, decreasing slightly at $\mathrm{pH} 7.0$ and $\mathrm{pH} 3.0$, but dropping sharply at $\mathrm{pH} 9.0$ (a decrease of $41 \%$ from that at $\mathrm{pH} 5.0$ ) as shown at figure 2 . Temperature and $\mathrm{pH}$ have been shown to have a significant effect on bacteriocin [40]. A bacteriocin from L. acidophilus could withstand heating at $75^{\circ} \mathrm{C}$ for $15 \mathrm{~min}$ [41]. Moreover, lactocin $\mathrm{RN} 78$ produced by $L$. casei RN 78 withstood heating up to $121^{\circ} \mathrm{C}$ for ${ }^{\circ} \mathrm{C} 15 \mathrm{~min}$ [42]. The bacteriocin of $L$. acidophilus NCIM5426 was found to be heat-stable $\left(12^{\circ} \mathrm{C}\right.$ for $\left.15 \mathrm{~min}\right)$ and active over a wide $\mathrm{pH}$ range of 4.0-10.0. It showed stability (60\%) for 30 days at room temperature. Heat and $\mathrm{pH}$ stability are important characteristics that would allow bacteriocins to act over a wide range of environmental conditions.

\section{Molecular weight determination}

Plate 2 shows the bands produced by the electrophoretic separation of the two bacteriocins in comparison to a marker of standard protein molecular weights. The molecular weights of both proteins were in the approximate range of $3-4 \mathrm{kDa}$. Similar molecular masses have been reported for curvacin A $(4.3 \mathrm{kDa})$ from Lactobacillus curvatus
LTH 1174 isolated from fermented sausage [43], curvaticin FS47 (4.07 $\mathrm{kDa}$ ) from Lactobacillus curvatus FS47 isolated from ground beef [28], curvaticin L442 (4.5kDa) from Lactobacillus curvatus L442, isolated from Greek traditional fermented sausage [44] and curvaticin LB65 from Lactobacillus curvatus LB65 [32].

Interestingly, a very wide variation is seen in the molecular weight of the inhibitory substances produced by pediococci. For instance, pediocin A, produced by $P$. pentosaceus FBB61 had a molecular weight of $80 \mathrm{kDa}$ [36], while $P$. pentosaceus $\mathrm{K} 34$ produced a bacteriocin (bacPPK34) of molecular weight of 2.5- $6.2 \mathrm{kDa}$ [45], and $P$. pentosaceus IE-3 produced a non-bacteriocin chemical peptide of only $1.7 \mathrm{kDa}$ [46]. Moreover, P. pentosaceus T1 produced an anti-listerial substance with an active fraction of molecular weight of $23 \mathrm{kDa}$ [15]. The latter are more likely Bacteriocin-Like Substances (BLIS).

\section{Mode of action of the two bacteriocins}

A strong inhibition of the growth of Staphylococcus aureus ATCC 43306, already growing for four $\mathrm{h}$, was obtained due to addition of the Lactobacillus curvatus M3 bacteriocin, where an increase of only $10 \%$ in optical density was obtained 5hours after addition of the bacteriocin as compared to an increase of $290 \%$ in the untreated control broth (Figure 3a). On re-culturing of the treated broth culture on fresh medium, no growth was obtained indicating bactericidal activity. It has been reported that curvaticin from Lactobacillus curvatus was bactericidal [32,47]. On the other hand, on addition of the Pediococcus pentosaceus N2 bacteriocin, growth of the indicator bacterium was greatly retarded. In the following five hours of incubation, an increase of only $45.6 \%$ in the optical density of the broth treated with the bacteriocin was recorded, as compared to an increase of $255.5 \%$ in the untreated broth (Figure $3 \mathrm{~b}$ ). However, on streaking of aliquots from the treated broth culture on fresh Nutrient Agar plates, growth was resumed after 24hours of incubation at $30^{\circ} \mathrm{C}$ indicating bacteriostatic activity. A similar finding on the bacteriostatic nature of pediocin has been reported [48].

\section{Production kinetics}

Figure $4 \mathrm{a}$ depicts the growth and bacteriocin production of L. curvatus M3 which showed an early increase in growth that continued up to $24 \mathrm{~h}$ from inoculation, after which a gradual decline 


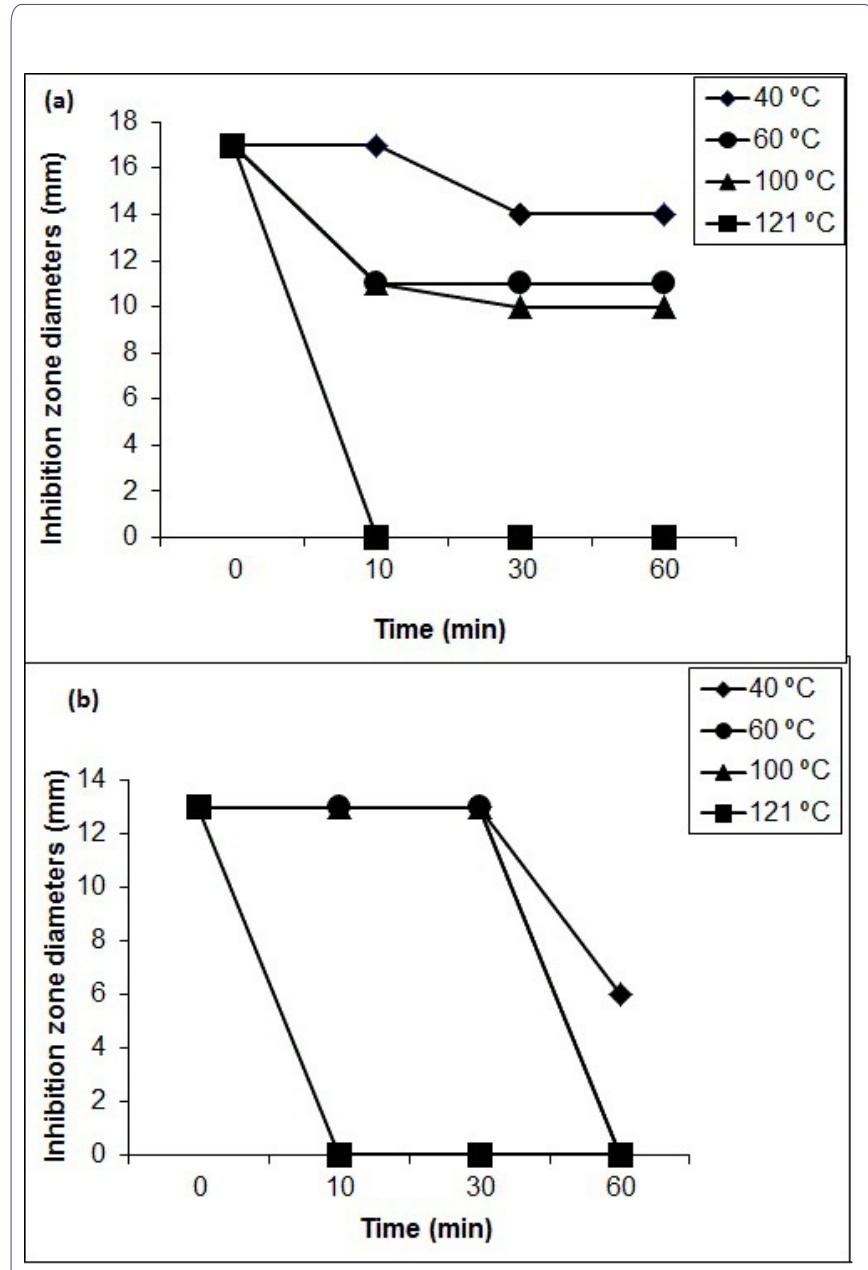

Figure 1: Effect of heating on activity of $L b$. curvatus $M 3$ bacteriocin.

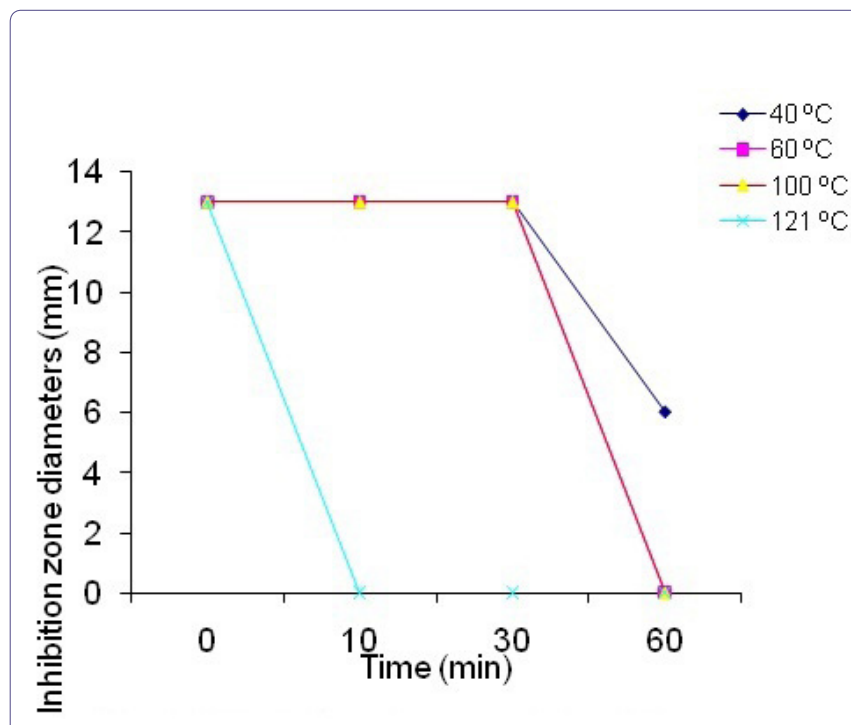

Figure 2: Effect of heating on activity of $P$. pentosaceus N2 bacteriocin.

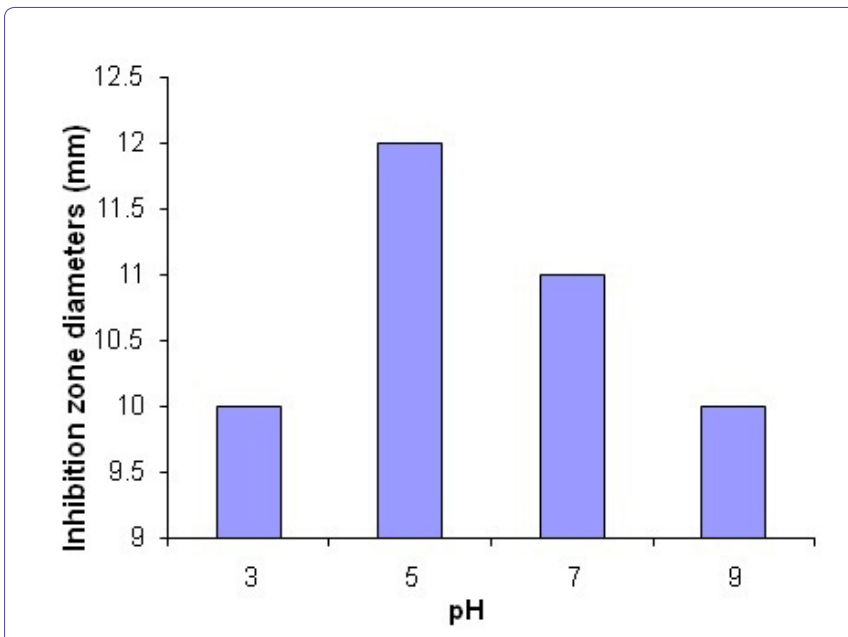

Figure 3a: Effect of $\mathrm{pH}$ on activity of bacteriocin from $L b$. curvatus M3.

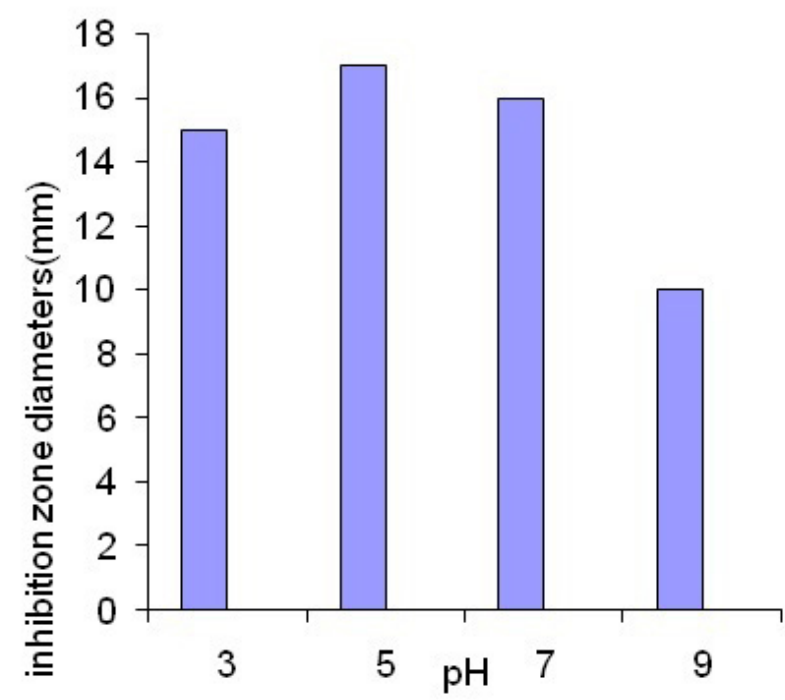

Figure 3b: Effect of $\mathrm{pH}$ on activity of bacteriocin from $P$. pentosaceus N2.

could be seen. The inhibitory activity could be detected as early as sixh from inoculation, with a gradual increase up to $12 \mathrm{~h}$, after which a steady state in activity was obtained with no decline up to $26 \mathrm{~h}$. A similar trend in bacteriocin production by L. curvatus LB65 has been reported [32], but the inhibitory activity declined within $24 \mathrm{~h}$. Maximum growth and activity were obtained at the $\mathrm{pH}$ value of 4.2 (Figure 4b).

Figure 5 shows that increase in growth of $P$. pentosaceus $\mathrm{N} 2$ was detectable since the start of the investigation, but the active growth phase seemed to start after $8 \mathrm{~h}$ from inoculation and continued up to the $25^{\text {th }}$ hour after which it started to decline. On the other hand, no antagonistic activity could be detected against Staph. aureus up to eight $\mathrm{h}$ of growth. Thenceforth, antagonistic activity began to be detected, and showed a steady increase up to $26 \mathrm{~h}$ of growth when the investigation was terminated. Maximal activity appeared to coincide with optimal growth, but also coincided with the drop in $\mathrm{pH}$ to the range of 4.5 to 4.2 cell growth and bacteriocin production are 


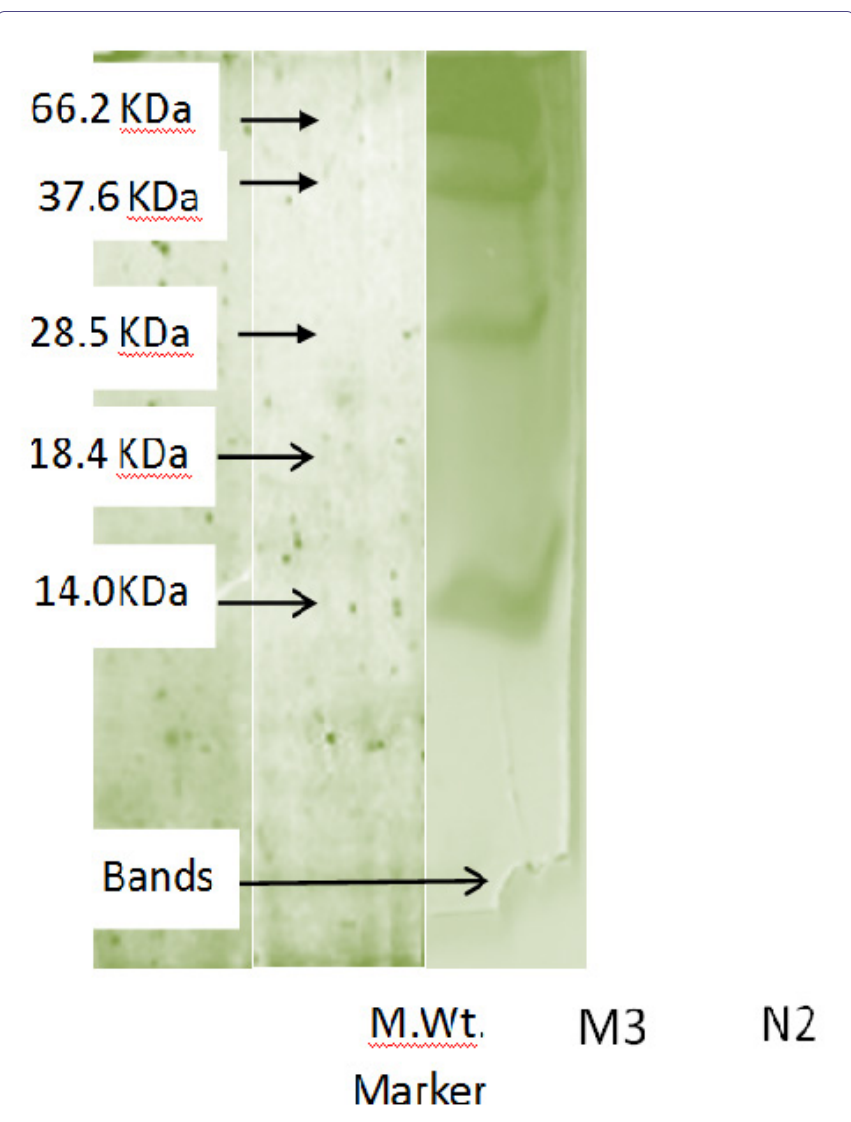

Figure 4a: Gel electrophoresis (SDS-PAGE) of the inhibitory moieties of L. curvatus $\mathrm{M} 3$ and $P$. pentosaceus N2 stained with Coomassie blue.

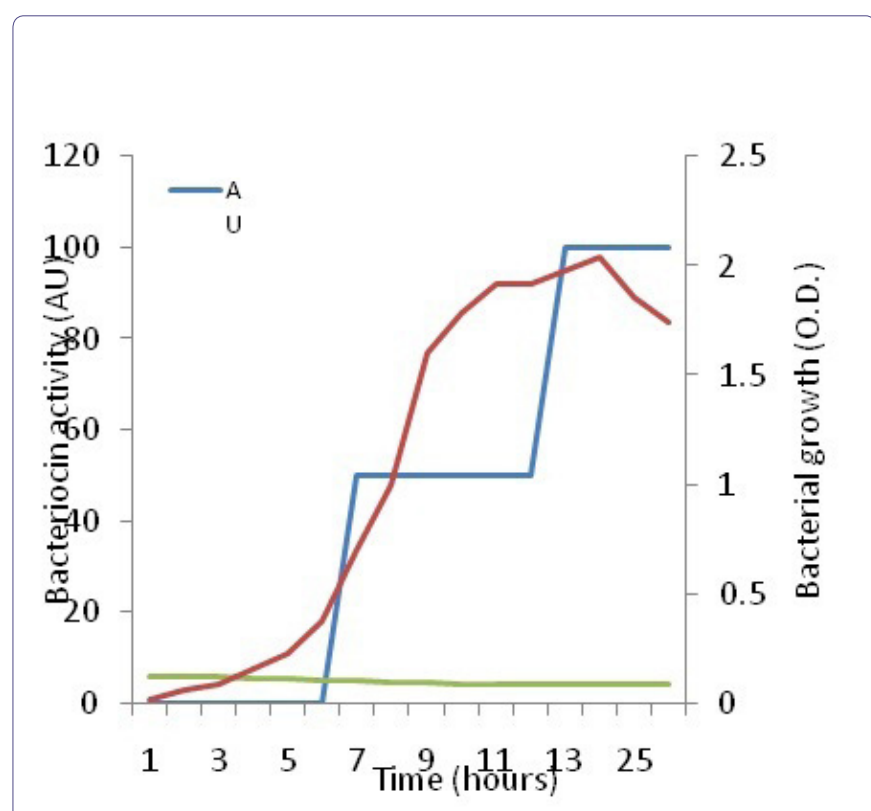

Figure $4 \mathrm{~b}$ : Kinetics of growth and bacteriocin production by Lb. curvatus M3.

influenced by temperature and $\mathrm{pH}$ as has been shown by many authors [49]. These authors showed that the highest bacteriocin activity occurred at a low constant temperature of $28^{\circ} \mathrm{C}$ and a constant $\mathrm{pH}$ of 5.4. The present results are in line with the finding that bacteriocin production is stimulated under unfavorable growth conditions such as low $\mathrm{pH}[13]$.

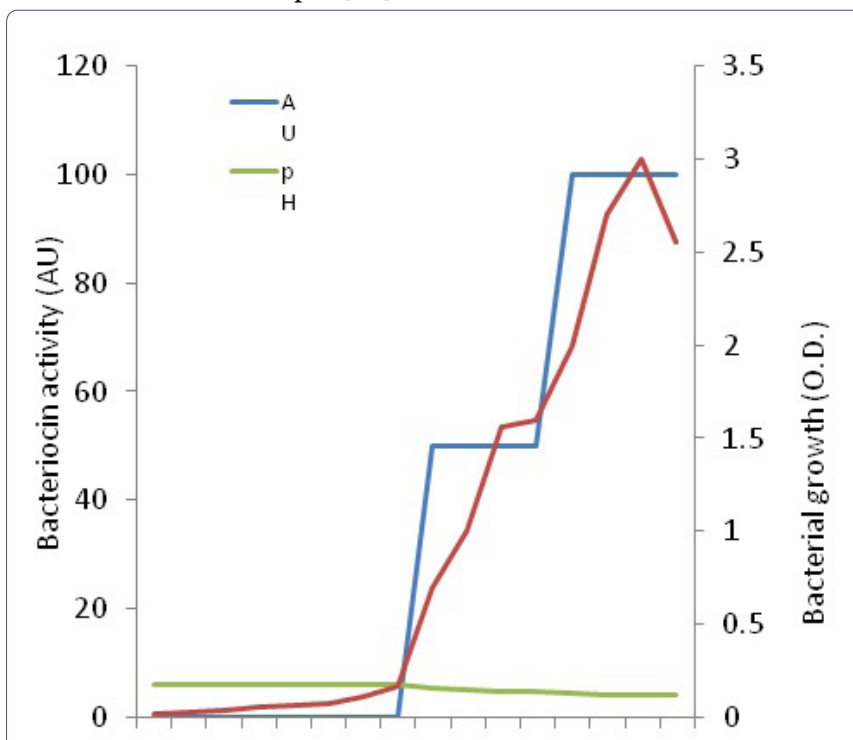

Figure 5: Kinetics of growth and bacteriocin production by P. pentosaceus N2.

\section{Conclusion}

This study determined the bacteriocinogenic capabilities of Lactobacillus curvatus M3 and Pediococcus pentosaceus N2 isolated from traditional fermented Sudanese beef (sharmoot) and newborn infant's faeces, respectively. Results of the study indicated the possible food preservation (M3) and clinical (N2) benefits of the two bacteria, and their possible utilization in these two aspect.

\section{References}

1. Ismail BB, Yusuf HL (2014) Consumer concerns about the use of additives in processed foods. Int J Cur Res 6: 65- 72

2. Soomoro AH, Masud T, Anwaar K (2002) Role of Lactic Acid Bacteria (LAB) in food preservation and human health - a review. Pak J Nutr 1: 20-24.

3. Alexandraki V, Tsakalidou E, Papadimitriou K, Holzapfel W (2013) Status and trends of the conservation and sustainable use of microorganisms in food processes. FAO Background Study Paper No. 65. FOOD and Agriculture Organization, Rome.

4. Galvez A, Lopez RL, Abriouel H, Valdivia E, Omar NB (2008) Application of bacteriocins in the control of foodborne pathogenic and spoilage bacteria. Crit Rev Biotechnol 28: 125-152.

5. De Vuyst L, Leroy F (2007) Bacteriocins from lactic acid bacteria: production, purification, and food applications. J Mol Microbiol Biotechnol 13: 194-199.

6. De Vuyst L, Vandamme EJ (1994) Antimicrobial potential of lactic acid bacteria. In: De Vuyst L, Vandamme EJ (eds.). Bacteriocins of Lactic Acid bacteria: Microbiology, Genetics and Applications. Springer US, USA. Pg no: 91-142.

7. Ennahar S, Sonomoto K, Ishizaki A (1999) Class Ila bacteriocins from lactic acid bacteria: antibacterial activity and food preservation. J Biosci Bioeng 87: 705-716.

8. de Man JC, Rogosa M, Sharpe ME (1960) A medium for the cultivation of lactobacilli. J Appl Bacteriol 23: 130-135.

9. Axelsson L (2004) Lactic acid bacteria: Classification and physiology. In: Salminen S, Wright AV, Ouwehand A (eds.). Lactic Acid Bacteria: Microbiological and Functional Aspects ( $3^{\text {rd }}$ edn). Marcel Dekker, New York. 
Citation: Elyass ME, Altayar MA, Mahdi AA, Abdelrawaf SS, Shigidi MT, et al. (2015) Characterization and Evaluation of Antimicrobial Activity of Bacteriocins from Lactobacillus Curvatus and Pediococcus Pentosaceus. J Infect Non Infect Dis 1: 001.

10. Schillinger U, Lüke FK (1987) Identification of lactobacilli from meat and meat products. Food Microbiol 4: 199-208.

11. Stiles ME, Holzapfel WH (1997) Lactic acid bacteria of foods and their current taxonomy. Int J Food Microbiol 36: 1-29.

12. Wood BJB, Holzapfel WH (1995) The Genera of Lactic Acid Bacteria. Spinger US, USA

13. Samelis J, Roller S, Metaxopuolos J (1994) Sakacin B, a bacteriocin produced by Lactobacillus sake isolated from Greek dry fermented sausages. J Appl Bacteriol 76: 475- 486

14. Schillinger U, Lücke FK (1989) Antibacterial activity of Lactobacillus sake isolated from meat. Appl Environ Microbiol 55: 1901-1906.

15. Jang S, Lee J, Jung U, Choi H-S, Suh HJ (2014) Identification of an anti-listerial domain from Pediococcus pentosaceus derived from Kimchi, a traditional fermented vegetable. Food Control 43: 42-48.

16. Barefoot SF, Klaenhammer TR (1983) Detection and activity of lactacin B, a bacteriocin produced by Lactobacillus acidophilus. Appl Environ Microbiol 45: $1808-1815$

17. Çadirci BH, Çitak S (2005) A comparison of two methods used for measuring antagonistic activity of lactic acid bacteria. Pak J Nutr 4: 237-241.

18. ten Brink B, Minekus M, van der Vossen JM, Leer RJ, Huis in't Veld JH (1994) Antimicrobial activity of lactobacilli: preliminary characterization and optimization of production of acidocin B, a novel bacteriocin produced by Lactobacillus acidophilus M46. J Appl Bacteriol 77: 140-148.

19. Ivanova I, Miteva V, Stefanova Ts, Pantev A, Budakov I, et al. (1998) Characterization of a bacteriocin produced by Streptococcus thermophilus 81 . Int J Food Microbiol 42: 147-158.

20. Lewus CB, Montville TJ (1991) Detection of bacteriocins produced by lactic acid bacteria. J Microbiol Meth 13: 145-150.

21. Faye T, Langsrud T, Nes IF, Holo H (2000) Biochemical and genetic characterization of propionicin T1, a new bacteriocin from Propionibacterium thoenii. Appl Environ Microbiol 66: 4230-4236.

22. Nilsen T, Nes IF, Holo H (2003) Enterolysin A, a cell wall-degrading bacteriocin from Enterococcus faecalis LMG 2333. Appl Environ Microbiol 69 2975-2984.

23. Ghrairi T, Frere J, Berjeaud JM, Manai M (2008) Purification and characterisation of bacteriocins produced by Enterococcus faecium from Tunisian rigouta cheese. Food Control 19: 162 -169.

24. van Reenen CA, Dicks LM, Chikindas ML (1998) Isolation, purification and partial characterization of plantaricin 423 , a bacteriocin produced by Lactobacillus plantarum. J Appl Microbiol 84: 1131-1137.

25. Mataragas M, Drosinos EH, Tsakalidou E, Metaxopoulos J (2004) Influence of nutrients on growth and bacteriocin production by Leuconostoc mesen teroides L124 and Lactobacillus curvatus L442. Antonie Van Leeuwenhoek 85: 191-198.

26. Rivas FP, Castro MP, Vallejo M, Marguet E, Campos CA (2014) Sakacin Q produced by Lactobacillus curvatus ACU-1: functionality characterization and antilisterial activity on cooked meat surface. Meat Sci 97: 475-479.

27. Garver KI, Muriana PM (1994) Purification and partial amino acid sequence of curvaticin FS47, a heat-stable bacteriocin produced by Lactobacillus curvatus FS47. Appl Environ Microbiol 60: 2191-2195

28. Mataragas M, Metaxopoulos J, Drosinos E (2002) Characterization of two bacteriocins produced by Leuconostoc mesenteroides L124 and LactobacilIus curvatus L442, isolated from dry fermented sausages. World J Microbiol Biotechnol 18: 847- 856 .

29. Castellano P, Holzapfel W, Vignolo G (2004) The control of Listeria innocua and Lactobacillus sakei in broth and meat slurry with the bacteriocinogenic strain Lactobacillus casei CRL705. Food Microbiol 21: 291- 298.
30. Vignolo G, Palacios J, Farías ME, Sesma F, Schillinger U, et al. (2000) Combined effect of bacteriocins on the survival of various Listeria species in broth and meat system. Curr Microbiol 41: 410-416.

31. Abdelbasset M, Manel D, Djamila K (2014) Purification and characterization of a novel bacteriocin produced by Lactobacillus curvatus LB65 isolated from Algerian traditional fresh cheese (Jben). Advances in Experimental Biology 8: $1222-1232$

32. Strasser de Saad AM, Pasteris SE, Manca de Nadra MC (1995) Production and stability of pediocin N5p in grape juice medium. J Appl Bacteriol 78: 473476

33. Todorov SD, Dicks LMT (2005) Pediocin ST18, an antilisterial bacteriocin produced by Pediococcus pentosaceus ST18 isolated from boza, a traditional cereal beverage from Bulgaria. Process Biochem 40: 365- 370.

34. Swetwiwathana A (2005) Microbiological quality enhancement of Thai fermented meat product (Nham) using Nham-associated pediocin-producing lactic acid bacteria (Pediococcus pentosaceus TISTR 536). Ph.D. Thesis, Department of Bioscience and Biotechnology, Kyushu University, Japan.

35. Todorov SD, Dicks LM (2009) Bacteriocin production by Pediococcus pentosaceus isolated from marula (Scerocarya birrea). Int J Food Microbiol 132 117-126.

36. Heng NCK, Wescombe PA, Burton JP, Jack RW, Tagg JR (2007) The Diversity of bacteriocins in Gram-positive bacteria. In: Riley MA, Chavan MA (eds.). Bacteriocins: Ecology and Evolution. Springer-Verlag, Berlin, Heidelberg.

37. Nghe D, Nguyen T (2014) Characterization of antimicrobial activities of Pediococcus pentosaceus Vtcc-B-601. J Appl Pharm Sci 4: 61- 64

38. Schillinger U, Lücke FK (1989) Antibacterial activity of Lactobacillus sake isolated from meat. Appl Environ Microbiol 55: 1901-1906.

39. Elamathy S, Kanchana D (2013) Characterization of heat stable and inhibitory activity of bacteriocin produced by Lactobacillus acidophilus. J Chem Tech 5: 1281-1283.

40. Mojgani N, Amirinia C (2007) Kinetics of growth and bacteriocin production in L. casei RN 78 isolated from a dairy sample in Iran. Int J Diary Sci 2: 1- 12.

41. Messens W, Verluyten J, Leroy F, De Vuyst $L$ (2003) Modelling growth and bacteriocin production by Lactobacillus curvatus LTH 1174 in response to temperature and $\mathrm{pH}$ values used for European sausage fermentation processes. Int J Food Microbiol 81: 41-52.

42. Strasser de Saad AM, Pasteris SE, Manca de Nadra MC (1995) Production and stability of pediocin N5p in grape juice medium. J Appl Bacteriol 78: 473 476

43. Abrams D, Barbosa J, Albano H, Silva J, Gibbs PA et al. (2011) Characterization of bacPPK34, a bacteriocin produced by Pediococcus pentosaceus strain K34 isolated from "Alheira". Food Control 22: 940- 946.

44. Singh PK, Sharma S, Kumari A, Korpole S (2014) A non-pediocin low molecular weight antimicrobial peptide produced by Pediococcus pentosaceus strain IE-3 shows increased activity under reducing environment. BMC Microbiol 14: 226- 234.

45. Bouttefroy A, Millière JB (2000) Nisin-curvaticin 13 combinations for avoiding the regrowth of bacteriocin resistant cells of Listeria monocytogenes ATCC 15313. Int J Food Microbiol 62: 65-75.

46. Díez L, Rojo-Bezares B, Zarazaga M, Rodríguez JM, Torres C, et al. (2012) Antimicrobial activity of pediocin PA-1 against Oenococcus oeni and other wine bacteria. Food Microbiol 31: 167-172.

47. Neysens P, Messens W, Gevers D, Swings J, De Vuyst L (2003) Biphasic kinetics of growth and bacteriocin production with Lactobacillus amylovorus DCE 471 occur under stress conditions. Microbiology 149: 1073-1082.

48. De Vuyst L, Callewaert R, Crabbe K (1996) Primary metabolite kinetics of bacteriocin biosynthesis by Lactobacillus amylovorus and evidence for stimulation of bacteriocin production under unfavourable growth conditions. Microbiology 142: 817- 827 